\title{
Incidence of perioperative respiratory complications in patients undergoing elective open upper abdominal surgery under general anaesthesia: Smokers versus non-smokers - An observational study
}

\author{
Sourabh Sengupta ${ }^{1}$, Maitreyee Mukherjee ${ }^{2}$, Prasenjit Dasgupta ${ }^{3}$, Sajib Chatterjee ${ }^{4}$, \\ Dipasri Bhattacharya ${ }^{5}$
}

${ }^{1}$ Specialist Medical Officer, Krishnagar Superspeciality Hospital,Nadia, ${ }^{2}$ Associate Professor, Department of Anaesthesia, IPGMER, Kolkata, ${ }^{3}$ Assistant Professor, ${ }^{4}$ Associate Professor, Department of General Surgery, Raiganj Government Medical College and Hospital, Raiganj, ${ }^{5}$ Professor, Department of Anaesthesia, R. G. Kar Medical College and Hospital, Kolkata, West Bengal, India

Background: Smoking has various deleterious effects and peri-operative complications. Pulmonary complications following abdominal surgery are frequent and associated with increased morbidity and mortality and length of hospital stay. Aims and Objectives: Hence, this study was done to observe the incidence of various respiratory and cardiovascular complications in the perioperative period in patients undergoing elective open upper abdominal surgery under general anaesthesia among smokers versus non-smokers. The various complications which are studied are as follows - Arterial desaturation, Severe coughing, Laryngospasm, Bronchospasm, Recurrent apnea, Variations in Mean Arterial Blood Pressure and Heart rates. Materials and Methods: Male patients ASA-I, II or III, aged 20-60 years undergoing elective open upper abdominal surgery under general anaesthesia were selected. They were divided into two groups (during pre-anaesthetic checkup) - smokers ( $>10$ cigarette/day for the past 1 year and continued smoking till admission), non-smokers (who never smoked). General anaesthesia was given according to standard protocol. Results: The smokers had higher incidence of laryngospasm as well as bronchospasm but they were not statistically significant. Smokers had low baseline $\mathrm{SpO}_{2}$; greater fall in $\mathrm{SpO}_{2}$ just after extubation, before sending to PACU and on day 1 which were statistically significant. Smokers had raised MAP just after extubation, on day 1 and day 2 which were statistically significant. Conclusion: Smokers had increased incidences of respiratory and hemodynamic complications than non-smokers.

Key words: GA; Haemodynamic complications; Non-smokers; Open upper abdominal surgery; Respiratory complications; Smoker

\section{INTRODUCTION}

Perioperative respiratory complications are a major concern of elective open upper abdominal surgery under G.A., and smoking is known to increase the frequency of complications. ${ }^{1-4}$ Despite this, the

\section{Access this article online}

Website:

http://nepjol.info/index.php/AJMS DOI: 10.3126/ajms.v13i3.41829

E-ISSN: 2091-0576

P-ISSN: 2467-9100

Copyright (c) 2022 Asian Journal of Medical Sciences

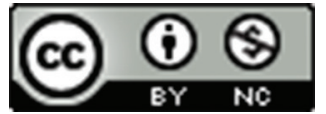

This work is licensed under a Creative Commons Attribution-NonCommercial 4.0 International License. 
levels. These adverse effects can explain the increased susceptibility to pulmonary complications. Smoking also alters the immune system. ${ }^{5}$

Carbon monoxide reduces oxygen transport and metabolism. Cyanide inhibits mitochondrial oxidative metabolism. These adverse events can explain the increased susceptibility to various pulmonary complications among smokers. As well as the causes of stormy induction of anaesthesia. Hence non-smokers are expected to have smoother perioperative period. ${ }^{6,7}$

Smoking cessation therapy appears to be more efficient when introduced before a surgical procedure and hence, the preoperative period might represent a golden moment for smoking cessation. Also longer period of preoperative smoking cessation is more beneficial. ${ }^{8,9}$ Still there would be a significant proportion of patients who would not be interested in smoking cessation as they have no interest in giving up smoking rather their smoking increases due to preoperative tension for the forthcoming procedure.

Again previous smokers have been found to suffer from relapse rates of $>50 \%,{ }^{10}$ and this may indicate that a significant percentage of this group would revert back to smoking during the follow-up period.

We have undertaken this study to observe the perioperative complications among smokers versus non-smokers undergoing elective open upper abdominal surgery under general anaesthesia.

\section{Aims and objectives}

1. To compare perioperative respiratory complications among smokers versus non-smokers undergoing elective open upper abdominal surgery under general anaesthesia,

2. To compare their haemodynamic effects and

3. To compare level of analgesia using Visual analogue scale (VAS) score.

\section{MATERIALS AND METHODS}

This prospective observational study was conducted at a tertiary Medical College and Hospital from January 2018 to June 2019 on 20-60-years-old male patients, posted for elective open upper abdominal surgery (except cardiothoracic surgeries) under general anaesthesia. ASA status I, II, III were included in the study.

\section{Sample size/design}

$\mathrm{Z} \alpha$ is a constant, set by convention according to the accepted alpha error. Here, it is 1.96 Similarly $Z \beta$ is 0.84 . Now from previously published study we get ${ }^{4}$,
P1 percentage of non-smokers having respiratory complications $=11 \%$ or 0.11

P2 percentage of smokers having respiratory complications $=20 \%$ or 0.20

And $\mathrm{P}=(\mathrm{P} 1+\mathrm{P} 2) / 2=0.155$

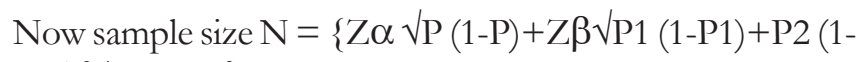
P2) $\}^{2} /(\mathrm{P} 1-\mathrm{P} 2)^{2}$

Now putting the values we get $\mathrm{N}=160$

The study was initiated after obtaining approval of the institutional ethics committee. The allocation was open level. Patients with ASA IV status, patients with psychoactive medication, COPD not being controlled by regular medication, comorbidities such as diabetes, hypertension, coronary artery disease and obstructive sleep apnoea and alcoholic patients were excluded from the study. Patients with anticipated difficult intubation were also excluded.

During pre-anaesthetic check up smoking history was taken along with the number of cigarettes smoked per day as well as the duration. Patients were instructed to stop smoking immedialy. Patients with pulmonary changes were optimized before surgery. Optimization was done by 1) Maintaining proper hydration, 2) Nebulization, 3) Antibiotic levofloxacin (500-750) mg OD, 4) Chest physiotherapy palpation, percussion, vibration, deep breathing, coughing and postural drainage.

The patients were divided into two groups - 1) smokers (>10 cigarettes/day for the past 1 year), 2) non-smokers (who never smoked). Lung function tests (mainly spirometry) were done to detect preoperative respiratory problems. Preoperative evaluation was done taking proper history, physical examinations, and routine pre-operative investigations $(\mathrm{Hb}$, blood sugar, serum urea, creatinine, chest X-ray, ecg).

All patients were premedicated with Tab Alprazolam $0.5 \mathrm{mg}$ oral, the night before surgery, Tab. Pantoprazole $(40 \mathrm{mg}$ ) oral at 6 A.M. and a minimum fasting state of $8 \mathrm{~h}$ before anaesthesia was ensured. In the theater, peripheral line was established. Intravenous crystalloid infusion was started and standard ASA monitors were attached. All patients were pre-oxygenated for 3 min with $100 \%$ oxygen. Premedications given with injection Midazolam $0.03 \mathrm{mg} / \mathrm{kg}$, Fentanyl $2 \mathrm{mcg} / \mathrm{kg}$ intravenously. Induction of anesthesia was done by Propofol $2 \mathrm{mg} / \mathrm{kg}$ and confirmed with loss of response to verbal commands followed by checking for bag-mask ventilation.

Intravenous suxamethonium $1.5 \mathrm{mg} / \mathrm{kg}$ was used for neuromuscular blockade. After one minute of bag-mask 
ventilation with $100 \%$, oxygen patient was intubated with appropriate size endotracheal tube. Position was checked by bilateral chest auscultation and $\mathrm{EtCO}_{2}$. Anaesthesia was maintained by nitrous oxide: oxygen (2:1) and sevoflurane. Loading dose of Atracurium was administered followed by intermittent boluses depending on need.

Haemodynamic and variation in oxygen saturation level monitoring was done every $5 \mathrm{~min}$ and was recorded.

At the end of surgery nitrous oxide was discontinued and residual neuromuscular blockade was reversed by Neostigmine $0.05 \mathrm{mg} / \mathrm{kg}$ and Glycopyrolate $0.005 \mathrm{mg} / \mathrm{kg}$. Patient was extubated after fulfilling extubation criteria.

The various parameters that were observed during the whole perioperative period are-

- Arterial desaturation: pulse oximetry $\left(\mathrm{SpO}_{2}\right)<92 \%$ for more than $1 \mathrm{~min}$.

- Laryngospasm: audible stridor or airway obstruction not relieved by airway manipulations.

- Bronchospasm: audible wheeze or unexplained increase in airway pressure.

- Mean arterial pressure (MAP).

- Heart rate (HR) and

- Level of analgesia using VAS score.

All the patients after operation were sent to Post Anaesthesia Care Unit (PACU) and observed for $48 \mathrm{~h}$ for any complications.

\section{Statistical analysis}

For statistical analysis, data were entered into a Microsoft Excel spreadsheet and then analyzed by SPSS (version 25.0; SPSS Inc., Chicago, IL, USA) and Graph Pad Prism version 5. Data had been summarized as mean and standard deviation for numerical variables and count and percentages for categorical variables. Two-sided sample $\mathrm{t}$-tests were used for a difference in mean involved in independent samples or unpaired samples. Paired t-tests were used as form of blocking and which had greater power than unpaired tests. A Chi-square test $\left(\chi^{2}\right.$ test) was used for statistical hypothesis test. "Chi-squared test" is often used as short for Pearson's Chi-squared test. Unpaired proportions were compared by Chi-square test or Fischer's exact test, as appropriate. $\mathrm{P} \leq 0.05$ was considered for statistically significant.

\section{RESULTS}

Demographical variable like age, weight,height and BMI were comparable in both the groups with no statistical difference which is shown in Table 1.

Difference of mean just after extubation MAP versus smoker and nonsmoker was statistically significant $(\mathrm{P}=0.0001)$.
Difference of mean day $1 \mathrm{MAP}$ versus smoker and nonsmoker was not statistically significant $(\mathrm{P}=0.3314)$. Difference of mean day 2 MAP versus smoker and nonsmoker was statistically significant $(\mathrm{P}=0.0006)$ shown in Table 2 and Figure 1.

Difference of mean just after intubation $H R$ versus smoker and nonsmoker was statistically significant $(\mathrm{P}=0.0021)$. Difference of mean $1 \mathrm{~h}$ intra-op HR versus smoker and nonsmoker was not statistically significant $(\mathrm{P}=0.1910)$. Difference of mean just after extubation $H R$ versus smoker and nonsmoker was statistically significant $(\mathrm{P}=0.0001)$. Others value were statistically not significant shown in Table 3 and Figure 2.

Difference of mean baseline $\mathrm{SpO}_{2}$ versus smoker and nonsmoker was statistically significant $(\mathrm{P}=0.0040)$, but the difference of mean value was not that clinically significant. Difference of mean just after extubation $\mathrm{SpO}_{2}$ versus smoker and nonsmoker was statistically significant $(\mathrm{P}=0.0049)$. Difference of mean before sending to ward $\mathrm{SpO}_{2}$ versus smoker and nonsmoker was statistically significant $(\mathrm{P} \leq 0.0001)$ shown in Table 4 and Figure 3.

Difference of mean VAS Score Day 1 morning versus smoker and nonsmoker was not statistically significant $(\mathrm{P}=0.5478)$. Difference of mean VAS Score Day 2 morning versus smoker and nonsmoker was not statistically significant $(\mathrm{P}=0.3034)$ shown in Table 5 and Figure 4.

In nonsmoker, $3(1.9 \%)$ patients had Arterial desaturation. In smoker, $12(7.5 \%)$ patients had Arterial desaturation. Association of Arterial desaturation $\left(\mathrm{SpO}_{2}<92 \%\right)$ versus smoker and nonsmoker was statistically significant $(\mathrm{P}=0.0344)$.

In nonsmoker, 160 (100.0\%) patients had no Bronchospasm. In smoker, $3(1.9 \%)$ patients had Bronchospasm. Association of Bronchospasm versus smoker and nonsmoker was not statistically significant $(\mathrm{P}=0.245)$ shown in Table 6.

\section{DISCUSSION}

In our study we found -

- The smokers had higher incidence of laryngospasm as well as bronchospasm but they were not statistically significant.

\begin{tabular}{|c|c|c|c|}
\hline \multicolumn{4}{|c|}{ Demographical variable of two groups: } \\
\hline Variable & $\begin{array}{c}\text { Nonsmoker }(160) \\
\text { Mean } \pm S D\end{array}$ & $\begin{array}{c}\text { Smoker }(160) \\
\text { Mean士SD }\end{array}$ & P-value \\
\hline Age & $46.906 \pm 9.944$ & $46.675 \pm 10.144$ & 0.837 \\
\hline Height $(\mathrm{cm})$ & $165.050 \pm 6.310$ & $165.918 \pm 6.644$ & 1.994 \\
\hline weight & $65.43 \pm 5.47$ & $65.994 \pm 5.762$ & 0.3710 \\
\hline BMI & $24.046 \pm 2.082$ & $24.0063 \pm 2.216$ & 0.868 \\
\hline
\end{tabular}

Asian Journal of Medical Sciences | Mar 2022 | Vol 13 | Issue 3 
Table 2: Distribution of mean MAP at different time interval : Smoker and Nonsmoker

\begin{tabular}{|c|c|c|c|c|c|c|c|}
\hline & Number & Mean & SD & Minimum & Maximum & Median & P-value \\
\hline \multicolumn{8}{|l|}{ Baseline MAP } \\
\hline Non Smoker & 160 & 80.1688 & 8.6644 & 65.0000 & 96.0000 & 81.0000 & \multirow[t]{2}{*}{0.2719} \\
\hline Smoker & 160 & 81.1938 & 7.9823 & 67.0000 & 97.0000 & 80.0000 & \\
\hline \multicolumn{8}{|c|}{ During induction MAP } \\
\hline Non Smoker & 160 & 78.4750 & 8.2041 & 64.0000 & 92.0000 & 79.5000 & \multirow[t]{2}{*}{0.2392} \\
\hline Smoker & 160 & 79.5375 & 7.9130 & 66.0000 & 94.0000 & 80.0000 & \\
\hline \multicolumn{8}{|c|}{ Just after intubation MAP } \\
\hline Non Smoker & 160 & 75.1813 & 8.9638 & 58.0000 & 94.0000 & 75.5000 & \multirow[t]{2}{*}{0.5260} \\
\hline Smoker & 160 & 75.8438 & 9.6905 & 55.0000 & 96.0000 & 77.0000 & \\
\hline \multicolumn{8}{|c|}{30 min intra-op MAP } \\
\hline Non Smoker & 160 & 75.8250 & 8.0263 & 63.0000 & 90.0000 & 76.0000 & \multirow[t]{2}{*}{0.4769} \\
\hline Smoker & 160 & 76.5063 & 9.0561 & 60.0000 & 100.0000 & 77.0000 & \\
\hline \multicolumn{8}{|c|}{$1 \mathrm{~h}$ intra-op MAP } \\
\hline Non Smoker & 160 & 76.5250 & 7.2224 & 65.0000 & 90.0000 & 76.0000 & \multirow[t]{2}{*}{0.8151} \\
\hline Smoker & 160 & 76.3125 & 8.9296 & 65.0000 & 99.0000 & 73.0000 & \\
\hline \multicolumn{8}{|c|}{ Just after extubation MAP } \\
\hline Non Smoker & 160 & 83.2563 & 7.8141 & 69.0000 & 100.0000 & 82.5000 & \multirow[t]{2}{*}{0.0001} \\
\hline Smoker & 160 & 86.7688 & 7.8044 & 70.0000 & 103.0000 & 88.0000 & \\
\hline \multicolumn{8}{|c|}{ Before sending to ward MAP } \\
\hline Non Smoker & 160 & 80.3750 & 7.3534 & 67.0000 & 92.0000 & 80.0000 & \multirow[t]{2}{*}{0.3314} \\
\hline Smoker & 160 & 81.1438 & 6.7701 & 65.0000 & 94.0000 & 80.0000 & \\
\hline \multicolumn{8}{|l|}{ Day 1 MAP } \\
\hline Non Smoker & 160 & 80.0688 & 7.3091 & 66.0000 & 94.0000 & 81.0000 & \multirow[t]{2}{*}{0.0013} \\
\hline Smoker & 160 & 82.6563 & 6.9735 & 68.0000 & 95.0000 & 81.0000 & \\
\hline \multicolumn{8}{|l|}{ Day 2 MAP } \\
\hline Non Smoker & 160 & 80.1313 & 7.2399 & 66.0000 & 93.0000 & 82.0000 & \multirow[t]{2}{*}{0.0006} \\
\hline Smoker & 160 & 82.9000 & 7.1315 & 70.0000 & 95.0000 & 82.0000 & \\
\hline
\end{tabular}

Table 3: Distribution of mean HR at different time interval: Smoker and Nonsmoker

\begin{tabular}{|c|c|c|c|c|c|c|c|}
\hline & Number & Mean & SD & Minimum & Maximum & Median & P-value \\
\hline \multicolumn{8}{|l|}{ Baseline HR } \\
\hline Non Smoker & 160 & 85.3000 & 9.7360 & 68.0000 & 110.0000 & 85.0000 & \multirow[t]{2}{*}{0.7967} \\
\hline Smoker & 160 & 85.5875 & 10.2081 & 65.0000 & 107.0000 & 85.0000 & \\
\hline \multicolumn{8}{|c|}{ During induction HR } \\
\hline Non Smoker & 160 & 83.2375 & 8.5344 & 68.0000 & 103.0000 & 83.0000 & \multirow[t]{2}{*}{0.7084} \\
\hline Smoker & 160 & 82.8813 & 8.4915 & 66.0000 & 100.0000 & 84.0000 & \\
\hline \multicolumn{8}{|c|}{ Just after intubation HR } \\
\hline Non Smoker & 160 & 96.1188 & 10.3221 & 77.0000 & 123.0000 & 93.0000 & \multirow[t]{2}{*}{0.0021} \\
\hline Smoker & 160 & 100.0813 & 12.4071 & 74.0000 & 130.0000 & 99.0000 & \\
\hline \multicolumn{8}{|c|}{30 min intra-op HR } \\
\hline Non Smoker & 160 & 78.0500 & 9.8401 & 56.0000 & 100.0000 & 78.0000 & \multirow[t]{2}{*}{0.3267} \\
\hline Smoker & 160 & 79.2625 & 12.1238 & 60.0000 & 129.0000 & 80.0000 & \\
\hline \multicolumn{8}{|l|}{$1 \mathrm{~h}$ intra-op HR } \\
\hline Non Smoker & 160 & 77.1750 & 8.5492 & 61.0000 & 96.0000 & 75.0000 & \multirow[t]{2}{*}{0.1910} \\
\hline Smoker & 160 & 78.5750 & 10.4656 & 62.0000 & 111.0000 & 76.0000 & \\
\hline \multicolumn{8}{|c|}{ Just after extubation HR } \\
\hline Non Smoker & 160 & 97.5813 & 12.7745 & 77.0000 & 133.0000 & 95.0000 & \multirow[t]{2}{*}{0.0001} \\
\hline Smoker & 160 & 103.1250 & 12.9054 & 85.0000 & 136.0000 & 100.0000 & \\
\hline \multicolumn{8}{|c|}{ Before sending to ward HR } \\
\hline Non Smoker & 160 & 85.9188 & 6.7320 & 70.0000 & 102.0000 & 86.0000 & \multirow[t]{2}{*}{0.7366} \\
\hline Smoker & 160 & 85.6750 & 6.2107 & 68.0000 & 98.0000 & 86.0000 & \\
\hline \multicolumn{8}{|c|}{ Day 1 morning HR } \\
\hline Non Smoker & 160 & 89.2313 & 5.2894 & 74.0000 & 98.0000 & 88.0000 & \multirow[t]{2}{*}{0.1527} \\
\hline Smoker & 160 & 88.3063 & 6.2172 & 70.0000 & 102.0000 & 89.0000 & \\
\hline \multicolumn{8}{|c|}{ Day 2 morning HR } \\
\hline Non Smoker & 160 & 87.8875 & 5.0232 & 75.0000 & 98.0000 & 88.0000 & \multirow[t]{2}{*}{0.6523} \\
\hline Smoker & 160 & 88.1938 & 6.9685 & 72.0000 & 105.0000 & 88.0000 & \\
\hline
\end{tabular}




\begin{tabular}{|c|c|c|c|c|c|c|c|}
\hline & Number & Mean & SD & Minimum & Maximum & Median & P-value \\
\hline \multicolumn{8}{|l|}{ Baseline $\mathrm{SpO}_{2}$} \\
\hline Non Smoker & 160 & 99.7000 & 0.5355 & 98.0000 & 100.0000 & 100.0000 & \multirow[t]{2}{*}{0.0040} \\
\hline Smoker & 160 & 99.4750 & 0.8238 & 97.0000 & 100.0000 & 100.0000 & \\
\hline \multicolumn{8}{|c|}{ During induction $\mathrm{SpO}_{2}$} \\
\hline Non Smoker & 160 & 99.8125 & 0.4371 & 98.0000 & 100.0000 & 100.0000 & \multirow[t]{2}{*}{0.6912} \\
\hline Smoker & 160 & 99.7938 & 0.4059 & 99.0000 & 100.0000 & 100.0000 & \\
\hline \multicolumn{8}{|c|}{ Just after intubation $\mathrm{SpO}_{2}$} \\
\hline Non Smoker & 160 & 99.5313 & 1.1098 & 94.0000 & 100.0000 & 100.0000 & \multirow[t]{2}{*}{0.3258} \\
\hline Smoker & 160 & 99.4063 & 1.1617 & 94.0000 & 100.0000 & 100.0000 & \\
\hline \multicolumn{8}{|c|}{30 min intra-op $\mathrm{SpO}_{2}$} \\
\hline Non Smoker & 160 & 99.9250 & 0.2642 & 99.0000 & 100.0000 & 100.0000 & \multirow[t]{2}{*}{0.0936} \\
\hline Smoker & 160 & 99.3813 & 4.0807 & 70.0000 & 100.0000 & 100.0000 & \\
\hline \multicolumn{8}{|l|}{$1 \mathrm{~h}$ intra-op $\mathrm{SpO}_{2}$} \\
\hline Non Smoker & 160 & 99.9438 & 0.2311 & 99.0000 & 100.0000 & 100.0000 & \multirow[t]{2}{*}{0.4023} \\
\hline Smoker & 160 & 99.8875 & 0.8164 & 94.0000 & 100.0000 & 100.0000 & \\
\hline \multicolumn{8}{|c|}{ Just after extubation $\mathrm{SpO}_{2}$} \\
\hline Smoker & 160 & 97.1250 & 4.7248 & 75.0000 & 100.0000 & 99.0000 & 0.0049 \\
\hline \multicolumn{8}{|c|}{ Before sending to ward $\mathrm{SpO}_{2}$} \\
\hline Non Smoker & 160 & 99.5438 & 0.9170 & 95.0000 & 100.0000 & 100.0000 & \multirow[t]{2}{*}{$<0.0001$} \\
\hline Smoker & 160 & 98.3063 & 1.8360 & 92.0000 & 100.0000 & 99.0000 & \\
\hline \multicolumn{8}{|c|}{ Day 1 morning $\mathrm{SpO}_{2}$} \\
\hline Non Smoker & 160 & 99.3875 & 0.8087 & 97.0000 & 100.0000 & 100.0000 & \multirow[t]{2}{*}{0.0278} \\
\hline Smoker & 160 & 99.0938 & 1.4743 & 94.0000 & 100.0000 & 100.0000 & \\
\hline \multicolumn{8}{|c|}{ Day 2 morning $\mathrm{SpO}_{2}$} \\
\hline Non Smoker & 160 & 99.5813 & 0.6865 & 98.0000 & 100.0000 & 100.0000 & \multirow[t]{2}{*}{0.0529} \\
\hline Smoker & 160 & 99.3688 & 1.2007 & 95.0000 & 100.0000 & 100.0000 & \\
\hline
\end{tabular}

\begin{tabular}{|c|c|c|c|c|c|c|c|}
\hline & Number & Mean & SD & Minimum & Maximum & Median & P-value \\
\hline \multicolumn{8}{|c|}{ VAS Score Day 1 morning } \\
\hline Non Smoker & 160 & 4.2625 & 1.3388 & 2.0000 & 8.0000 & 4.0000 & \multirow[t]{2}{*}{0.5478} \\
\hline Smoker & 160 & 4.3563 & 1.4465 & 2.0000 & 8.0000 & 5.0000 & \\
\hline \multicolumn{8}{|c|}{ VAS Score Day 2 morning } \\
\hline Non Smoke & 160 & 4.4188 & 1.3984 & 1.0000 & 8.0000 & 5.0000 & \multirow[t]{2}{*}{0.3034} \\
\hline Smoker & 160 & 4.5875 & 1.5271 & 1.0000 & 8.0000 & 5.0000 & \\
\hline
\end{tabular}

\begin{tabular}{|c|c|c|c|c|}
\hline Variable & $\begin{array}{c}\text { Non } \\
\text { smoker }\end{array}$ & smoker & $\begin{array}{c}\text { Chi-square } \\
\text { value }\end{array}$ & P-value \\
\hline \multicolumn{5}{|c|}{ Laryngospasm } \\
\hline No & 157 & 154 & 0.457 & 0.49 \\
\hline Yes & 3 & 6 & & \\
\hline \multicolumn{5}{|c|}{ Arterial desaturation } \\
\hline No & 157 & 148 & 4.476 & 0.034 \\
\hline Yes & 3 & 12 & & \\
\hline \multicolumn{5}{|c|}{ Bronchospasm } \\
\hline No & 160 & 157 & 1.346 & 0.245 \\
\hline Yes & 0 & 3 & & \\
\hline
\end{tabular}

- Smokers had low baseline $\mathrm{SpO}_{2}$; fall in $\mathrm{SpO}_{2}$ just after extubation, before sending to PACU and on day 1 which were statistically significant.

- Smokers had more arterial desaturation $\left(\mathrm{SpO}_{2}<92 \%\right)$ than non-smokers which was statistically significant.

- Smokers had raised MAP just after extubation, on day 1 and day 2 which were statistically significant.

- Smokers had incidences of raised HRs just after intubation and just after extubation which were also statistically significant.
- Postoperative VAS scores among smokers and nonsmokers were statistically not significant.

Myles et al., ${ }^{4}$ found that smokers had increased incidences of respiratory complications (i.e. laryngospasm, bronchospasm or fall in $\mathrm{SpO}_{2}$ ) Our study confirms to the study of Myles et al. We have found the incidence of laryngospasm and bronchospasm was higher among smokers group though not statistically significant. But higher fall of $\mathrm{SpO}_{2}$ was significantly lower in smoker group during baseline, just after extubation, before sending to ward and on day 1 . These effects are probably due to effects of general anaesthesia and more ventilation perfusion mismatch in smokers. ${ }^{4}$ This fall in $\mathrm{SpO}_{2}$ was also supported by the study of Dennis et al., ${ }^{10}$ Graybill et al., ${ }^{11}$ also found that the smokers had higher incidences of respiratory complications compared to non-smokers. Chandrashekar et al., ${ }^{12}$ stated smokers had increased incidences of haemodynamic complications compared to non-smokers. We have got similar results.

Rodrigo ${ }^{13}$ found that smokers had overall raised blood pressure, HR and systemic vascular resistance as compared to nonsmokers. Our study conforms to the studies of Chandrashekar 


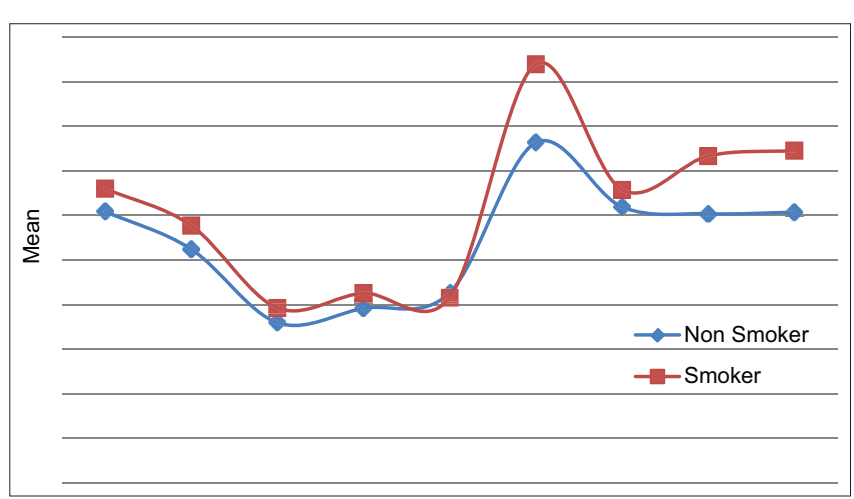

Figure 1: Changes of mean arterial pressure at various time points between the two groups

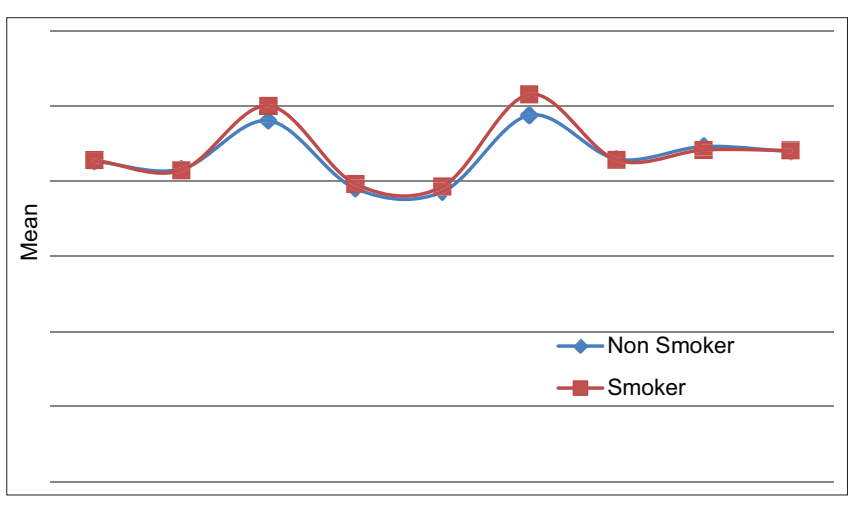

Figure 2: Difference of mean BP at various time points

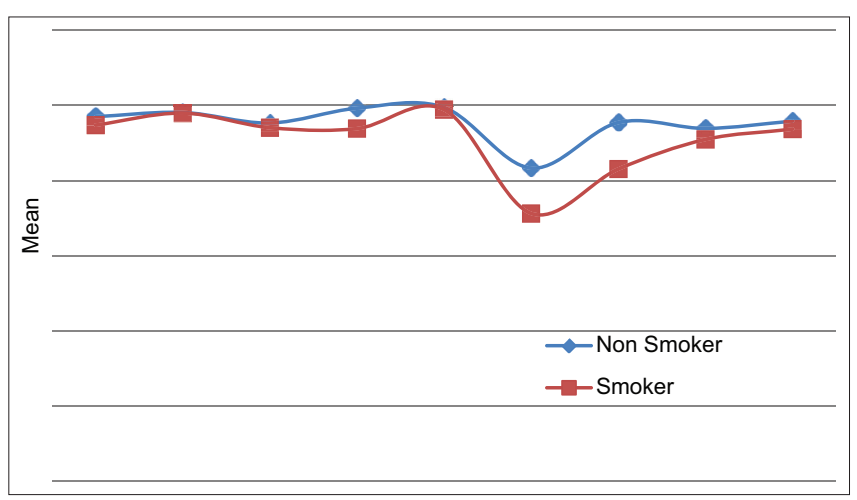

Figure 3: Difference of $\mathrm{SpO}_{2}$ between two groups

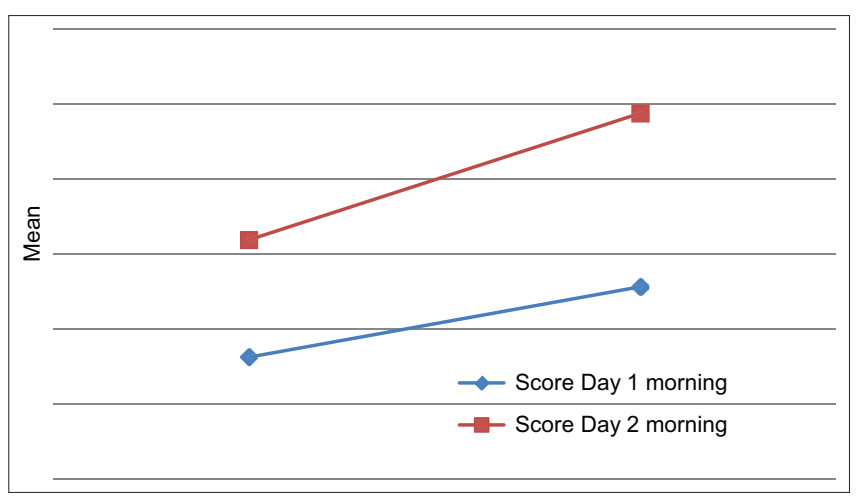

Figure 4: Difference of visual analogue scale between two groups et al., ${ }^{12}$ and Rodrigo. ${ }^{13}$ We found that MAP was significantly raised among smokers than non-smokers just after intubation and extubation, on day 1 and day 2 as compared to nonsmokers. The smokers were also found to have significantly raised HRs just after intubation and extubation as compared to non-smokers. These might be because of the higher levels of nicotine in blood among smokers than non-smokers. Our study was also supported by the study of Miskovic and Lump ${ }^{14}$ who also showed that smokers suffered from high blood pressure. Chiang et al., ${ }^{15}$ stated that smokers suffered from higher pain intensity and required more the study of Dennis et al., ${ }^{10}$ Graybill et al., ${ }^{11}$ also found that the smokers had higher incidences of respiratory complications compared to non-smokers.

Chandrashekar et al., ${ }^{12}$ stated smokers had increased incidences of haemodynamic complications compared to non-smokers. We have got similar results. Rodrigo ${ }^{13}$ found that smokers had overall raised blood pressure, HR and systemic vascular resistance as compared to non-smokers. Our study conforms to the studies of Chandrashekar et al., ${ }^{12}$ and Rodrigo. ${ }^{13}$ We found that MAP was significantly raised among smokers than non-smokers just after intubation and extubation, on day 1 and day 2 as compared to non-smokers. The smokers were also found to have significantly raised $\mathrm{HRs}$ just after intubation and extubation as compared to non-smokers. This might be because of the higher levels of nicotine in blood among smokers than non-smokers. Our study was also supported by the study of Miskovic and Lump ${ }^{14}$ who also showed that smokers suffered from high blood pressure. Upadhyay et al., ${ }^{16}$ Chiang et al., ${ }^{15}$ stated that smokers suffered from higher pain intensity and required more opiate analgesics during the first $72 \mathrm{~h}$ postoperatively as compared to non-smokers. But in our study, we assessed the level of analgesia using VAS score for $48 \mathrm{~h}$ postoperatively which was statistically non-significant between smokers and non-smokers. This might be because of the analgesic coverage provided post-operatively. Chiang et al., ${ }^{15}$ also found that there were more number of male smokers whose average age were less than the female smokers. For excluding gender bias we selected only male patients. In our study, the mean age, height, weight and BMI among smokers and non-smokers were statistically non-significant.

Smoking perioperatively increases the chances of the development of various pulmonary complications. Cessation of smoking any time before surgery is beneficial. Patients can be motivated by assurance, nicotine gum or patch, inhaler or various pharmacotherapy such as bupropion.

\section{Limitations of the study}

The notable shortcomings of this study are:

1. Breath $\mathrm{CO}$ analyzer or Urine Cotinine level cannot be done to confirm or refute a history of smoking.

2. The study has been done in a single center.

3. The study was carried out in a tertiary care hospital and open label, so hospital bias and confounding bias cannot be ruled out. 
4. Some of the patients possibly on different medications, which were not given by patients for properly during study and evaluation.

5. Non-smokers having passive smoke inhalation were not taken into account.

\section{CONCLUSION}

In our study, we found that smokers had increased incidences of respiratory and haemodynamic complications than non-smokers.

\section{ACKNOWLEDGMENT}

Late Prof UK Sarkar who was with us during planning stage, Dr Tapobrata who helped in statistical analysis

\section{REFERENCES}

1. Kruschewski M, Rieger $\mathrm{H}$ and Pohlen $\mathrm{U}$. Risk factors for clinical anastomotic leakage and postoperative mortality in elective surgery for rectal cancer. Int J Colorectal Dis. 2007;22(8):919-927. https://doi.org/10.1007/s00384-006-0260-0

2. Alves $A$, Panis $Y$ and Mathieu P. Mortality and morbidity after surgery of mid and low rectal cancer. Results of a French prospective multicentric study. Gastroenterol Clin Biol. 2005;29(5):509-514.

https://doi.org/10.1016/s0399-8320(05)82121-9

3. Pappachen S, Smith PR and Shah S. Postoperative pulmonary complications after gynecologic surgery. Int J Gynaecol Obstet. 2006;93(1):74-76.

https://doi.org/10.1016/j.ijgo.2006.01.014

4. Myles PS, lacono GA, Hunt JO, Hunt JO, Fletcher H, Morris J, et al. Risk of respiratory complications and wound infection in patients undergoing ambulatory surgery: Smokers versus nonsmokers. Anesthesiology. 2002;97(4):842-847.

https://doi.org/10.1097/00000542-200210000-00015

5. Khuri SF, Henderson WG and DePalma RG. Determinants of long-term survival after major surgery and the adverse effect of postoperative complications. Ann Surg. 2005;242(3):326-341

https://doi.org/10.1097/01.sla.0000179621.33268.83

6. Panagiotakos DB, Pitsavos C and Chrysohoou C. Effect of exposure to secondhand smoke on markers of inflammation: The ATTICA study. Am J Med. 2004;116(3):145-150. https://doi.org/10.1016/j.amjmed.2003

7. Velicer WF, Prochaska JO and Rossi JS. Assessing outcome in smoking cessation studies. Psychol Bull. 1992;111(1):23-41 https://doi.org/10.1037/0033-2909.111.1.23

8. Castleden CM and Cole PV. Carboxyhaemoglobin level of smokers and non-smokers working in the City of London. $\mathrm{Br} \mathrm{J}$ Ind Med. 1975;32(2):115-118.

https://doi.org/10.1136/oem.32.2.115

9. Myers K, Hajek P, Hinds C and McRobbie H. Stopping smoking shortly before surgery and postoperative complications: A systematic review and meta-analysis. Arch Intern Med. 2011;171(11):983-989. https://doi.org/10.1001/archinternmed.2011.97

10. Dennis A, Curran J, Sherriff $J$ and Kinnear W. Effects of passive and active smoking on induction of anaesthesia. $\mathrm{Br} \mathrm{J}$ Anaesth. 1994;73(4):450-452. https://doi.org/10.1093/bja/73.4.450

11. Graybill WS, Frumovitz M, Nick AM, Wei C, Mena GE, Soliman PT, et al. Impact of smoking on perioperative pulmonary and upper respiratory complications after laparoscopic gynecologic surgery. Gynecol Oncol. 2012;125(3):556-560. https://doi.org/10.1016/j.ygyno.2012.03.020

12. Chandrashekar N, Prabhakara GN, Shivakumarappa GM, Venkatesh $\mathrm{N}$ and Rangarajan A. Study of smoking cessation and its intra and postoperative benefits. J Evol Med Dent Sci. 2013;2(51):10020-10028.

13. Rodrigo C. The effects of cigarette smoking on anesthesia. Anesth Prog. 2000;47(4):143-150.

14. Miskovic $A$ and Lump AB. Postoperative pulmonary complications. Br J Anaesth. 2017;118(3):317-334. https://doi.org/10.1093/bja/aex002

15. Chiang $\mathrm{HL}$, Chia YY, Lin HS and Chen $\mathrm{CH}$. The implications of tobacco smoking on acute postoperative pain: A prospective observational study. Pain Res Manag. 2016;2016:9432493 https://doi.org/10.1155/2016/9432493

16. Upadhyay SP, Samant U, Tellicherry SS, Chauhan $H$ and Mallick PN. Prevention of postoperative acute lung injury (ALI)the anaesthetist role. Int J Anesthetic Anesthesiol. 2015;2:27 https://doi.org/10.23937/2377-4630/2/2/1027

\section{Authors Contribution:}

SS- Initial manuscript preparation, investigation drafting; MM- Concept and design of study; PD- Revision of manuscript,interpretation of results;

SC- Coordination, revision, statistical interpretation; DB- Critical analysis, revision

Work attributed to:

R.G. Kar Medical College and Hospital, Kolkata, West Bengal, India

Orcid ID:

Dr. Sourabh Sengupta - (1) https://orcid.org/0000-0003-0237-4287

Dr. Maitreyee Mukherjee - (i) https://orcid.org/0000-0001-5054-0927

Dr. Prasenjit Dasgupta - (1) https://orcid.org/0000-0002-9966-2535

Dr. Sajib Chatterjee - (1) https://orcid.org/0000-0002-9340-1705

Dr. Dipasri Bhattacharya - (i) https://orcid.org/0000-0002-9001-1525

Source of Support: None, Conflicts of Interest: None. 